\title{
Er det sammenheng mellom vitamin D-nivåer og dødelighet?
}

\author{
Tilskudd av vitamin $D_{3}$ var assosiert med redusert dødelighet hos eldre \\ voksne, men tilskudd av det plantebaserte vitamin $\mathrm{D}_{2}$ hadde ikke en slik \\ effekt.
}

Det publiseres flere og flere studier om sammenhengen mellom vitamin D og ulike sykdommer, men hvilken betydning vitamin D har for sykdomsrisiko er fortsatt omdiskutert. I en metaanalyse har en internasjonal forskergruppe undersøkt om vitamin D-nivået og

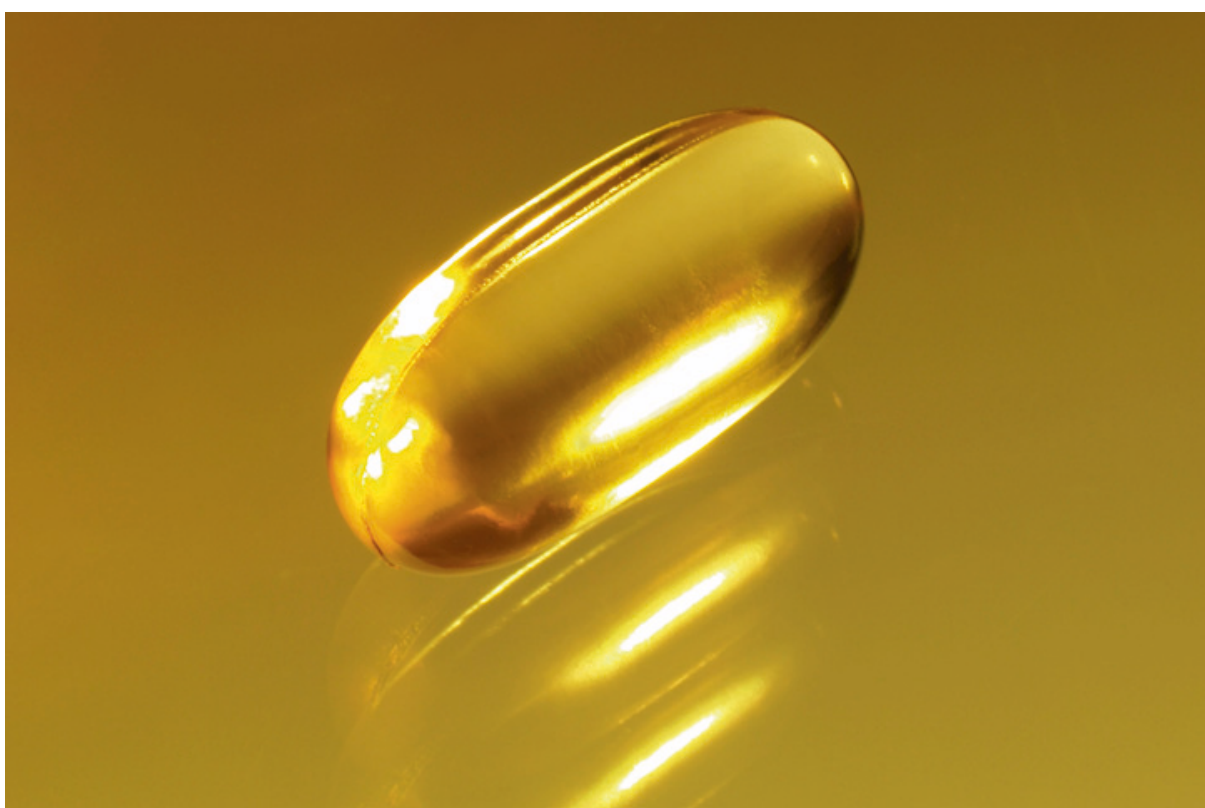

Foto: Sue Hiscoe/NTB scanpix vitamin D-tilskudd er forbundet med mortalitet av ulike sykdommer (1).

Resultater fra observasjonsstudier viste en omvendt assosiasjon mellom sirkulerende 25-hydroksyvitamin D-konsentrasjon, som er den primære indikatoren for

vitamin D-status, og risiko for all død og død av kardiovaskulær sykdom, kreft og andre sykdommer. I randomiserte studier var relativ risiko for død av all sykdom redusert ved tilskudd av vitamin $\mathrm{D}_{3}$ (RR 0,89, $95 \% \mathrm{KI}$ 0,80-0,99), mens vitamin $\mathrm{D}_{2}$-tilskudd ikke førte til noen endring i dødelighet.

- Selv om observasjonsstudier viser en konsistent sammenheng mellom lave vitamin D-nivåer og risiko for sykdom, er vi usikre på hva denne kan skyldes, sier forsker Trude Eid Robsahm ved Kreftregisteret. To mulige forklaringer er at sykdom forårsaker lave vitamin D-nivåer (revers kausalitet), eller at vitamin D hemmer sykdomsprosesser. Styrken med denne studien er at den inkluderer et relativt høyt antall randomiserte studier, som kunne ha gitt oss svar på dette spørsmålet. Resultatene var imidlertid ikke overbevisende.

- Jeg er enig med forfatterne, som maner til forsiktighet når det gjelder intervensjon og inntak av vitamin $D$ så lenge man ikke vet om vitamin $\mathrm{D}$-metabolittene $\mathrm{D}_{2}$ og $\mathrm{D}_{3}$ har ulik betydning for sykdomsrisiko eller hvilken dose og varighet av inntak som er optimal, sier Robsahm.

\section{Trine B. Haugen \\ Tidsskriftet \\ Litteratur \\ 1. Chowdhury R, Kunutsor S, Vitezova A et al. Vitamin $D$ and risk of cause specific death: systematic review and meta-analysis of observational cohort and randomised intervention studies. BMJ 2014: 348: g1903}

\section{Pasientinformasjon påvirker medikamentvalg}

\section{Leger informerer ofte pasientene om effekten av behandling. Det er ikke likegyldig på hvilken måte de gir slik informasjon.}

I 2013 hentet nesten en halv million pasienter ut en resept på statiner på norske apotek. Effekten av kolesterolsenkende medisiner på hjerte- og karsykdom er godt dokumentert, men hvordan skal legen forklare pasientene hvor stor effekten er? Livslang statinbehandling kan forlenge livet med mer enn 12 måneder, men langt mindre for de fleste pasienter. Alternativt kan vi uttrykke den samme effekten som absolutt reduksjon i risiko for å dø de neste ti årene; denne kan være opptil $4 \%$.

I Danmark dekker trygden en årlig «forebyggingssamtale» hos fastlegen. Her vil legen blant annet vurdere risiko for hjerte- og karsykdom og eventuelt forskrive et statin. $\mathrm{Vi}$ randomiserte 34 danske allmennleger til enten å informere aktuelle pasienter om livsforlengelse eller absolutt risikoreduksjon ved bruk av statiner (1). 112 pasienter fikk informasjon om livsforlengelse ved en eventuell statinbehandling, mens 128 fikk informasjon om absolutt risikoreduksjon. Andelen som hevet minst én statinresept på apotek var $5 \%$ i den første gruppen, mot $25 \%$ i den andre. Denne forskjellen var høysignifikant. Begge pasientgrupper var like fornøyde med den informasjonen de hadde fått. Gruppene var nokså like med hensyn til risikofaktorer, men legene som informerte om absolutt risikoreduksjon, opplevde noe større arbeidsbelastning.

Undersøkelsen viser at den måten som legen forklarer effektstørrelsen på, kan ha stor betydning for valg av behandling. Våre funn kan tyde på at effekten blir oppfattet som større når den presenteres som absolutt risikoreduksjon enn livsforlengelse, men vi vet ikke sikkert om forskjellen i reseptuthenting skyldes legens eller pasientens vurdering. Vi vet heller ikke hvilken informasjonstype som er best. Helseministeren ønsker at pasientene skal spille en større rolle i valg av behandling. Vår studie tyder på at dette kan få stor betydning for medisinsk praksis.

\section{Ivar Sønbø Kristiansen}

Avdeling for helseledelse og helseøkonom Universitetet i Oslo

\section{Litteratur}

1. Harmsen CG, Kristiansen IS, Larsen PV et al. Communicating risk using absolute risk reduction or prolongation of life formats: cluster-randomised trial in general practice. $\mathrm{Br} J$ Gen Pract 2014 64: e199-207. 